\title{
Phytophthora Species Associated with Plants in Constructed Wetlands and Vegetated Channels at a Commercial Plant Nursery Over Time
}

\author{
Garrett A. Ridge ${ }^{1,3}$, Natasha L. Bell ${ }^{2}$, Andrew J. Gitto ${ }^{1}$, \\ Steven N. Jeffers ${ }^{1}$, and Sarah A. White ${ }^{1,4}$
}

ADDITIONAL INDEX WORDs. aquatic plants, ecological water treatment, plant pathogens

Summary. Constructed wetlands have been used for decades in agricultural settings to remediate nutrients and other agrichemicals from irrigation runoff and drainage; however, little is known about the presence and distribution of Phytophthora species within irrigation runoff water being treated in constructed wetlands. Therefore, we collected plant samples from within vegetated runoff collection channels and treatment stages of two constructed wetland systems receiving irrigation runoff at a commercial plant nursery in Cairo, GA, to determine if roots of wetland plants were infested by species of Phytophthora. Samples were collected 12 times, at 1 - to 2 month intervals, over a 19-month period, from Mar. 2011 through Sept. 2012. The sample period covered all four seasons of the year, so we could determine if the association of Phytophthora species with roots of specific plant species varied with season. Approximately 340 samples from 14 wetland plant species were collected, and 22 isolates of Phytophthora species were recovered. Phytophthora species were typically isolated from plants in channels receiving runoff water directly from plant production areas; Phytophthora species were not detected on plants where water leaves the nursery. No seasonal patterns were observed in plant infestation or presence of species of Phytophthora. In fact, Phytophthora species were rarely found to be associated with the roots of the wetland plants collected; species of Phytophthora were found infesting roots of only $6.5 \%$ of the 336 plants sampled. Species of Phytophthora were not found to be associated with the roots of golden canna (Canna flaccida), lamp rush (Juncus effusus var. solutus), duckweed (Lemna valdiviana), or sedges (Carex sp.) during the study period. The exotic invasive plant species marsh dayflower [Murdannia keisak (33\% of samples infested)] and alligatorweed [Alternanthera philoxeroides (15\% of samples infested)] were found to have the first and third highest, respectively, incidences of infestation, with smooth beggartick (Bidens laevis) having the second highest incidence of samples infested $(22 \%)$. Management of invasive species in drainage canals and constructed wetland systems may be critical because of their potential propensity toward infestation by Phytophthora species. Plant species recommended for further investigation for use in constructed wetlands to remediate irrigation runoff include golden canna, marsh pennywort (Hydrocotyle umbellata), pickerelweed (Pontederia cordata), and broadleaf cattail (Typha latifolia). The results from this study provide an important first look at the associations between species of Phytophthora and wetland plants in constructed wetland systems treating irrigation runoff and will serve to further optimize the design of constructed wetlands and other vegetation-based treatment technologies for the removal of plant pathogens from irrigation runoff.

A s competition for freshwater resources and the potential for more restrictive water use regulations increase, nursery and greenhouse plant producers require information related to the use and quality of alternative water sources to ensure continued and economically sustainable crop production. Recycled irrigation runoff is one alternative water source growers are increasingly considering; however, one major barrier limiting adoption of irrigation water reuse is the perceived potential for infection of crops by plant pathogens present in recycled water (Hong and Moorman,
2005; Hong et al., 2014; White et al., 2013). Numerous studies have demonstrated a positive correlation between irrigating plants with plant pathogen-contaminated water and disease incidence (Klotz et al., 1959; McIntosh, 1966; Shokes and McCarter, 1979; Whiteside and Oswalt, 1973; Yamak et al., 2002). Furthermore, MacDonald et al. (1997) concluded that recycled irrigation water can harbor significant levels of plant pathogen propagules. Researchers hypothesize that pathogens could be spread from a small number of infected plants to an entire nursery if propagules are present in recycled irrigation water (Pettitt et al., 1998). A number of chemical or physical treatments, such as chlorination, ozonation, and ultraviolet light, can effectively eliminate propagules of Phytophthora species and other water-borne plant pathogens from water (Hong and Moorman, 2005; Hong et al., 2014; Stewart-Wade, 2011 ). However, the cost of installation and maintenance of these treatment systems is a major factor limiting their use (Majsztrik et al., 2017). In addition, treating irrigation water with chlorine or ozone may result in the formation of chemical byproducts that can be toxic to plants and humans at high exposure concentrations (Agency for Toxic Substances and Disease Registry, 2010; Hong and Moorman, 2005).

Constructed wetlands are designed to mimic the biological and chemical filtration characteristics and capacity of natural wetlands. Constructed wetland systems have been used to treat wastewater from many sources, including municipalities, agriculture, landfills, urban areas, and highways (Hammer, 1992; Vymazal, 2011; Vymazal et al., 2006; White et al., 2010). In nurseries and greenhouses, constructed wetlands and vegetated channels are used to remove fertilizers and pesticides from

\begin{tabular}{llll}
\hline $\begin{array}{l}\text { Units } \\
\text { To convert U.S. to SI, } \\
\text { multiply by }\end{array}$ & U.S. unit & SI unit & $\begin{array}{l}\text { To convert SI to U.S., } \\
\text { multiply by }\end{array}$ \\
\hline 0.4047 & $\mathrm{acre}(\mathrm{s})$ & $\mathrm{ha}$ & $2.471 \mathrm{l}$ \\
29,574 & $\mathrm{fl} \mathrm{oz}$ & $\mu \mathrm{L}$ & $3.3814 \times 10^{-5}$ \\
29.5735 & $\mathrm{fl} \mathrm{oz}$ & $\mathrm{mL}$ & 0.0338 \\
0.3048 & $\mathrm{ft}_{0.0929}$ & $\mathrm{~m}$ & 3.2808 \\
2.54 & $\mathrm{ft}^{2}$ & $\mathrm{~m}^{2}$ & 10.7639 \\
25.4 & inch $(\mathrm{es})$ & $\mathrm{cm}$ & 0.3937 \\
$\left({ }^{\circ} \mathrm{F}-32\right) \div 1.8$ & inch $(\mathrm{es})$ & $\mathrm{mm}$ & 0.0394 \\
& ${ }^{\circ} \mathrm{F}$ & ${ }^{\circ} \mathrm{C}$ & $\left({ }^{\circ} \mathrm{C} \times 1.8\right)+32$
\end{tabular}


runoff (Taylor et al., 2006; White, 2018). If constructed wetlands could be designed to manage plant pathogens in irrigation runoff at commercial plant nurseries, they could provide an alternative to chemical treatments and potentially be used for removing both biological (pathogen, algae, weed seeds) and chemical (pesticide, nutrient, metal) contaminants in runoff.

Species of Phytophthora are among the most common plant pathogens found in irrigation water, presumably because these oomycetes produce swimming, motile zoospores that are freely and readily dispersed in moving water (Erwin and Ribeiro, 1996; Hong and Moorman, 2005; Hong et al., 2014). However, the susceptibility of common hydrophytic (wetland) plant species to infection by species of Phytophthora and the ability of these plants to potentially remove propagules of Phytophthora species from runoff water must be characterized to optimize the design and function of constructed wetland systems and vegetated runoff channels. By identifying wetland plant species that do not attract or are not susceptible to species of Phytophthora for use in these treatment systems, the likelihood that wetland

Received for publication 4 Feb. 2019. Accepted for publication 29 Apr. 2019.

Published online 5 August 2019.

This material is based on work that is supported by the National Institute of Food and Agriculture, U.S. Department of Agriculture, under award number 2014-51181-22372 and project numbers SC-1700539, SC-1700445, and SC-1700309, and under USDA-ARS specific cooperative agreement no. 58-6618-2-0209 for "Environmental Resource Management Systems for Nurseries, Greenhouses, and Landscapes," which was part of the USDA-ARS Floriculture and Nursery Research Initiative. Technical Contribution No. 6740 of the Clemson University Experiment Station. The authors thank K. Van Kampen, N. Brinton, D. Drechsler, C. Ridge, D. Tyrpak, L. Luszcz, and S. Sharpe for technical assistance.

This paper is based on information presented during the Clean WateR3 program sessions, held as part of the ASHS Annual Conference, 30 July to 3 Aug. 2018 in Washington, DC.

${ }^{1}$ Department of Plant and Environmental Sciences, Clemson University, Clemson, SC 29634

${ }^{2}$ Department of Environmental Engineering and Earth Sciences, Clemson University, Clemson, SC 29634

${ }^{3}$ Current address: Novozymes North America Inc., Durham, NC 27709

${ }^{4}$ Corresponding author. E-mail: swhite4@clemson. edu.

This is an open access article distributed under the CC BY-NC-ND license (https://creativecommons.org/ licenses/by-nc-nd/4.0/).

https://doi.org/10.21273/HORTTECH04300-19 plants will function as inoculum sources could be reduced. Therefore, the two objectives of this study were as follows: 1) to determine if species of Phytophthora were associated with the roots of plants established in vegetated channels and stages within constructed wetland systems treating irrigation runoff at a commercial plant nursery; and 2) to determine if these associations were affected by time of year.

\section{Materials and methods}

STUdy LOCATION. The field study was conducted at a large wholesale nursery in Cairo, GA. Root samples were collected repeatedly from 14 plant species growing in vegetated channels, hereafter referred to as runoff collection channels, and stages within constructed wetlands to determine potential associations with species of Phytophthora (Table 1). Samples were collected 12 times over a 19-month period from Mar. 2011 through Sept. 2012 to characterize seasonal variability in the association of Phytophthora species with the roots of these 14 wetland plant species. Constructed wetland 1 (CWl) was a 7.7-acre, free-water surface constructed wetland system that treated irrigation runoff collected from a 120-acre nursery production area in two stages (Fig. 1). The design and hydrology of CWl were discussed previously (White et al., 2010). Briefly, water from the production area was channeled through a runoff collection channel into a retention pond and then pumped into stage 1 of the wetlands. Water flowed from stage 1 into stage 2 of the wetlands and then was discharged into stilling ponds after treatment. The second constructed wetland (CW2) was 4 acres in size and received irrigation runoff collected from 217 acres of nursery production area using a four-stage, free-water surface, vegetated wetland design (Fig. 2). The design and hydrology of CW2 also were discussed previously (White, 2018). Briefly, water from the production area flowed through a runoff collection channel into a retention pond and then was pumped into stage 1 . Water flowed from stage 1 into stages 2 and 3 and then into the first and second stilling ponds (site 16) before being released off-site.
Sixteen specific sampling locations were designated along runoff collection channels and in stages of the two constructed wetlands (Figs. 1 and 2). Locations for sample sites were selected to represent various stages of water treatment. Sites 1, 2, 3,14 , and 15 were located in runoff collection channels that moved water from production areas into retention ponds. Locations for sites $4,5,6,10$, and 11 were chosen to sample the middle of the constructed wetlands. Sites 7,8 , and 12 represent final stages of wetland treatment, and sites 9 and 16 were located where treated water was discharged into the environment.

SAMPle COLlection AND PROCESSING. On each sample date, root systems from two or three wetland plant species were sampled from $10-\mathrm{m}^{2}$ plots within each designated site, stored in sealable plastic bags, and transported in a cooled ice chest to the laboratory. In the laboratory $(<12 \mathrm{~h}$ after plants were collected), plant roots were stored at $15^{\circ} \mathrm{C}$ in the dark until processed, and roots were processed within $6 \mathrm{~d}$ of collection. Roots were rinsed thoroughly under running tap water, 7 to 10 root pieces (1 to $2 \mathrm{~cm}$ in length) were excised from each plant, and these were embedded in PARPH-V8, a medium selective for Phytophthora species (Ferguson and Jeffers, 1999; Jeffers, $2015 \mathrm{~b}$ ). Isolation plates were held for 3 to $7 \mathrm{~d}$ at $20{ }^{\circ} \mathrm{C}$ in the dark and inspected regularly for colonies of Phytophthora species. Colonies of Phytophthora species were subcultured on fresh PARPH-V8 and then stored on $5 \%$ clarified V8 agar (Erwin and Ribeiro, 1996) in $8-\mathrm{mL}$ glass vials at $15{ }^{\circ} \mathrm{C}$ in the dark.

IDENTIFICATION OF PHYTOPHTHORA SPECIES. All isolates were tentatively confirmed to be species of Phytophthora based on sporangium morphology and oospore production characteristic of the genus Phytophthora (Erwin and Ribeiro, 1996). To produce sporangia, cultures of each isolate were grown on 10\% V8 juice agar (Jeffers, 2015a). Agar plugs $(5 \mathrm{~mm}$ diameter) from the advancing margins with actively growing hyphae were transferred to a 60-mm-diameter petri dish and covered with $1.5 \%$ nonsterile soil extract solution (Jeffers and Aldwinckle, 1987). Petri plates were placed under 
Table 1. Samples from 14 different plant species were collected from 16 sites in two constructed wetland systems that received runoff water at a commercial plant nursery in Georgia and were assayed for the presence of naturally occurring species of Phytophthora.

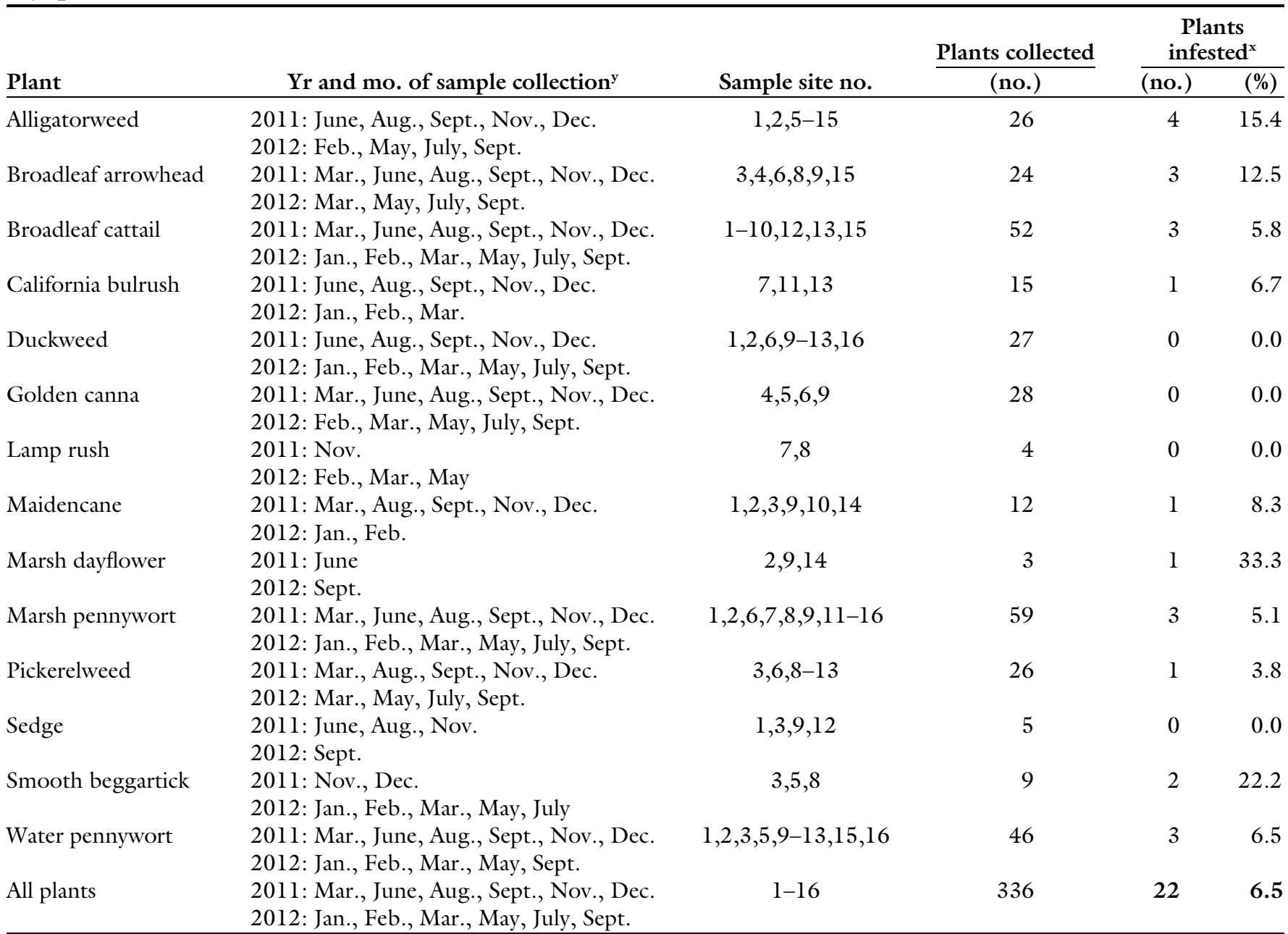

${ }^{\mathrm{z}}$ The two constructed wetlands were designated CW1 and CW2 and are depicted in Figs. 1 and 2.

y Plant samples were collected at 1- to 2-month intervals for 19 months, from Mar. 2011 through Sept. 2012.

${ }^{x}$ Plant samples were assayed in the laboratory without surface disinfestation; therefore, plants from which Phytophthora species were isolated were considered to be infested.

continuous fluorescent light at room temperature $\left(22\right.$ to $\left.25^{\circ} \mathrm{C}\right)$ and examined after 12 to $24 \mathrm{~h}$. The shape of sporangia, presence of papillae, and type of sporangiophore were observed microscopically $(\times 40$ to $\times 200)$. Sporangia were classified as papillate if papilla appeared as a full hemisphere, semipapillate if papillae were conspicuous but appeared as less than a full hemisphere, and nonpapillate if papillae were inconspicuous (data not shown) (Erwin and Ribeiro, 1996). To produce oospores, isolates were grown on super clarified V8 juice agar [sV8A (Jeffers, 2015c; Jeffers and Aldwinckle, 1988)] at $20^{\circ} \mathrm{C}$ in the dark for 6 weeks. Isolates that produced oospores were classified as homothallic and those that did not produce oospores were classified as heterothallic. Antheridium attachment (paragynous or amphigynous) was evaluated if oospores were formed (data not shown). Isolates tentatively identified as species of Phytophthora were later verified by DNA sequencing to identify the species of each isolate.

To confirm identification of individual isolates, mycelium mats for each isolate were grown in a 60-mm-diameter petri dish containing $10 \%$ clarified V8 broth $[\mathrm{cV} 8 \mathrm{~b}$ (Jeffers, 2015a)]. Cultures were incubated at $25^{\circ} \mathrm{C}$ in the dark for $3 \mathrm{~d}$, and then mycelium mats were collected with forceps and washed with distilled water to remove broth. The DNeasy Plant Mini Kit (Qiagen, Germantown, MD) was used to extract genomic DNA from mycelium mats. Mycelium mats of each isolate were placed in 2-mL screw-top tubes containing $200 \mu \mathrm{L}$ of $0.5-\mathrm{mm}$ glass beads, one $5-\mathrm{mm}$ glass bead, 400 $\mu \mathrm{L}$ of kit buffer $\mathrm{APl}$, and $4 \mu \mathrm{L}$ of kit RNase A. Tubes were homogenized at maximum speed for $1.5 \mathrm{~min}$ in a homogenizer (Mini Beadbeater-8; Biospec Products, Bartlesville, OK). The DNeasy Plant Mini Kit DNA extraction protocol was followed after bead homogenization.

Initially, all isolates had the nuclear ribosomal DNA internal transcribed spacer (ITS) locus amplified by polymerase chain reaction (PCR) using primers ITS6 and ITS4 for species identification (Cooke et al., 2000; White et al., 1990). Isolates that produced ITS sequences with double peaks were suspected to be putative hybrid species of Phytophthora. These isolates were re-grown by producing single-zoospore colonies to ensure 


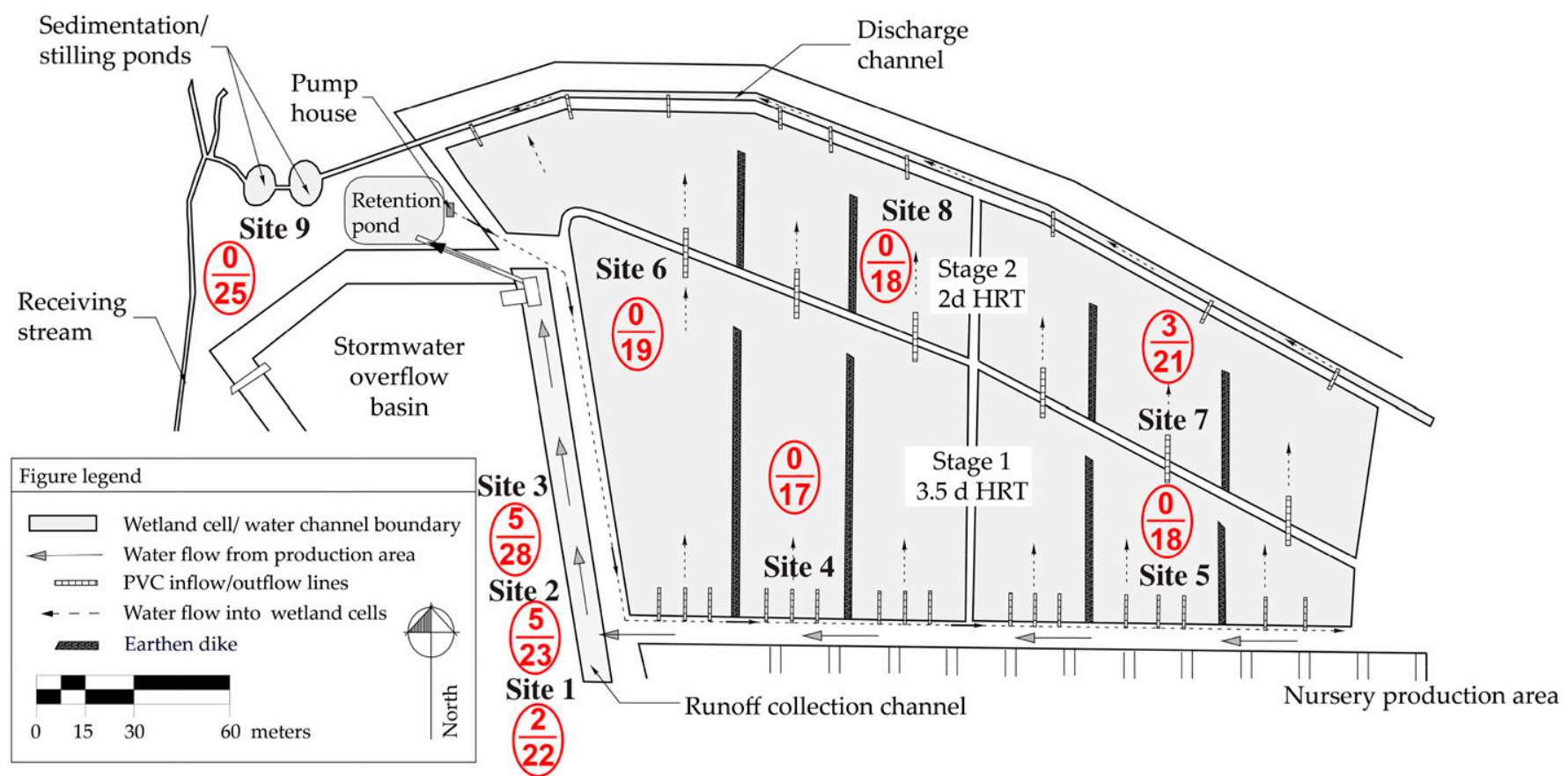

Fig. 1. Collection sites within constructed wetland system 1 (CW1): Water flowed from the runoff collection channel into a retention pond. Water was then pumped from the retention pond into stage 1 . Arrows represent water flow through each stage of the system, and circled numbers indicate the numbers of plants infested with species of Phytophthora (top number) and the numbers of plants sampled at each collection site (bottom number). HRT = hydraulic retention time, PVC = polyvinyl chloride. $1 \mathrm{~m}=3.2808 \mathrm{ft}$.

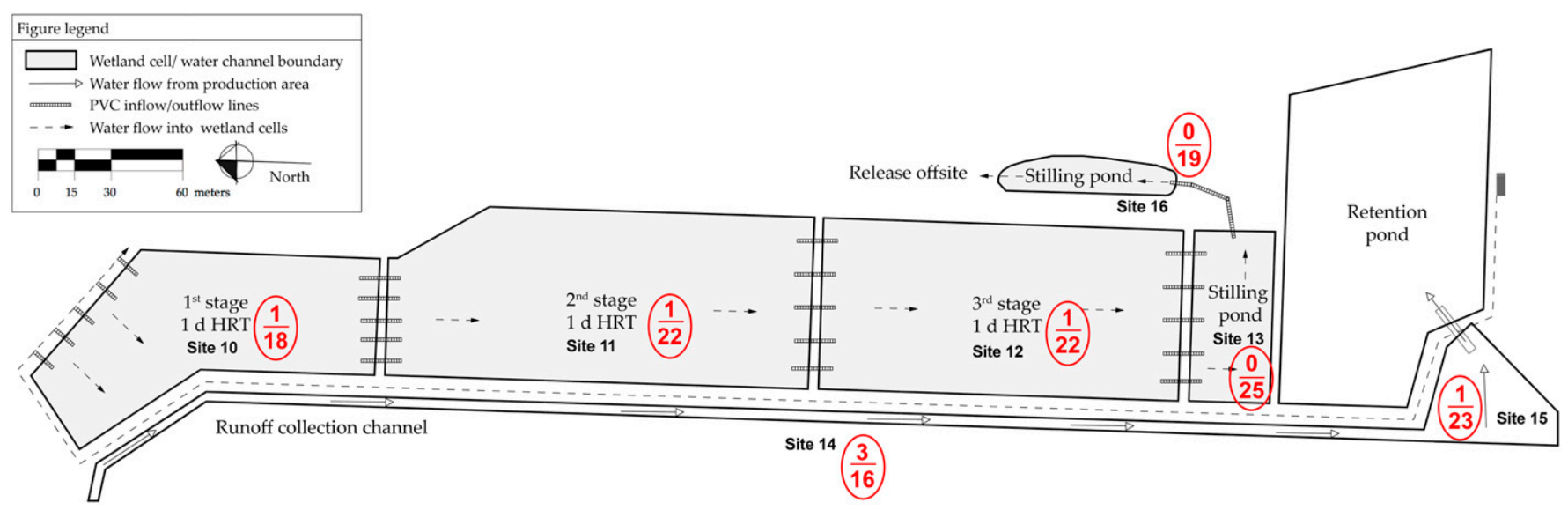

Fig. 2. Collection sites within constructed wetland system 2 (CW2): Water flowed from the runoff collection channel into a retention pond. Water was pumped from the retention pond into stage 1 . Arrows represent water flow through the wetland, and circled numbers indicate numbers of plants infested with species of Phytophthora (top number) and the numbers of plants sampled at each collection site (bottom number). HRT $=$ hydraulic retention time, $\mathrm{PVC}=$ polyvinyl chloride. $1 \mathrm{~m}=3.2808 \mathrm{ft}$.

axenic cultures were present, and three genomic DNA loci were amplified: the ITS locus and two uniparental, maternally inherited, mitochondrial DNA loci (Burgess, 2015): cytochrome oxidase subunits 1 and $2(\cos 1$ and $\operatorname{cox} 2$, respectively). The coxl and $\operatorname{cox} 2$ loci were sequenced using primers OomCoxl-levup/OomCoxl-levlo for coxl and primers Cox2-F/Cox2RC4 for $\operatorname{cox} 2$ (Choi et al., 2015). PCR mixtures for all loci contained $17.0 \mu \mathrm{L}$ of molecular biology grade water, 2.5 $\mu \mathrm{L}$ : of $10 \times$ PCR buffer $\left(\right.$ no $\mathrm{MgCl}_{2}$ ), $2.5 \mu \mathrm{L}$ of $1.0 \mathrm{~mm}$ dNTPs, $1.0 \mu \mathrm{L}$ of $50 \mathrm{mM} \mathrm{MgCl} 2,0.5 \mu \mathrm{L}$ of $25 \mu \mathrm{M}$ of each primer, $0.25 \mu \mathrm{L}$ of Platinum II Taq Hot-Start DNA Polymerase (Thermo Fisher Scientific, Waltham, $\mathrm{MA}$ ), and $1.0 \mu \mathrm{L}$ of genomic DNA. PCR conditions for ITS, coxl, and cox2 amplification were $4 \mathrm{~min}$ at $95^{\circ} \mathrm{C}$, then 36 cycles of $95^{\circ} \mathrm{C}$ for 40 $\mathrm{s}, 55^{\circ} \mathrm{C}$ for $40 \mathrm{~s}, 72^{\circ} \mathrm{C}$ for $1 \mathrm{~min}$, and then a final extension at $72{ }^{\circ} \mathrm{C}$ for 5 min (Choi et al., 2015). Before sequencing, PCR products were purified with ExoSAP-IT (Affymetrix, Cleveland, $\mathrm{OH}$ ).

PCR products were bidirectionally Sanger-sequenced at the Yale Keck DNA Sequencing Laboratory (New Haven, CT). The sequencing 
primers were the same ones used for PCR amplification. The forward and reverse bidirectional sequences were trimmed and aligned to create consensus sequences using Geneious Prime (version 2019.1.1; Biomatters, Auckland, New Zealand). Sequences were used to identify Phytophthora species using BLAST analysis in the National Center for Biotechnology Information (NCBI, Bethesda, MD) GenBank BLASTn and the curated Phytophthora-ID database (Grünwald et al., 2011). Phytophthora-ID database ITS sequence alignments with the highest percentage match (i.e., at least $99.5 \%$ identical nucleotide sequences) were used for species identification. The species of the maternal parent of the putative hybrids of species of Phytophthora were identified by using NCBI Genbank BLASTn to align the coxl and cox 2 sequences of hybrid isolates with sequences in the NCBI Genbank database; only sequences that matched 100\% were accepted.

\section{Results}

Identification of Phrtophthora SPECIES. Root systems were not surface-disinfested before isolating $\mathrm{Phy}$ tophthora species; therefore, it is not known if colonies of Phytophthora species recovered from root pieces grew from propagules on the surface of the roots or from hyphae that had penetrated the roots. Consequently, roots from which Phytophthora species were isolated were designated as infested and not infected. For this study, Phytophthora species were determined to be associated with a given plant species if the roots were infested. Only one species of Phytophthora was recovered from each infested plant, and a single isolate was subcultured from each species and saved for identification.

In all, 22 isolates were recovered from the roots of 22 infested wetland plants during this study, and these isolates represented eight different species-like groups (Table 2, Fig. 3). For clarity and simplicity, these eight groups are referred to as species in this document. Ten isolates were identified as six established species (Yang et al., 2017): four isolates of Phytophthora drechsleri, two isolates of Phytophthora citrophthora, and one isolate each of Phytophthora cryptogea, Phytophthora inundata, Phytophthora nicotianae, and Phytophthora virginiana. Three isolates were identified as Phytophthora taxon personii, a species that has yet to be formally described (Burgess et al., 2018). Six isolates with identical DNA sequences (designated as Phytophthora Clade 9 hybrid) were identified as putative hybrids with ITS sequences that had double peaks and sequences of the maternal mitochondrial genes cox 1 and cox2 matching several species in Phytophthora Clade 9: P. virginiana, Phytophthora bydropathica, and Phytophthora parsiana (Martin et al., 2014; Yang and Hong, 2013; Yang et al., 2017). Three isolates (designated Phytophthora sp.) were confirmed to be species of Phytophthora by morphology, but these isolates were lost in long-term storage so could not be identified to species.

Association of Phrtophthora SPECIES WITH WETLAND PLANTS OVER TIME. In all, 336 wetland plant samples were collected during 12 sampling events over the 19-month study period, from Mar. 2011 through Sept. 2012, and 22 of these plants were infested by species of Phytophthora (Table 1). Species of Phytophthora consistently were isolated from one or more wetland plants on each sample date except for Jan. 2012 (Fig. 3). Phytophthora species were detected on root systems of four plants on two sample dates: Nov. 2011 [maidencane (Panicum bemitomon), marsh pennywort, pickerelweed, and smooth beggartick] and Mar. 2012 [broadleaf cattail, marsh pennywort, and twice on water pennywort (Hydrocotyle ranunculoides)] (Table 2, Fig. 3). Detections of Phytophthora species on these two sampling dates represented the highest incidence of infestation of wetland plants during the study.

Plant species were not distributed equally within the constructed wetlands, and their presence throughout the study period varied among seasons. Consequently, only 10 of the 14 plant species were sampled over all four seasons: alligatorweed, smooth beggartick, golden canna, water pennywort, marsh pennywort, duckweed, maidencane, pickerelweed, broadleaf arrowhead (Sagittaria latifolia), and broadleaf cattail (Table 1). However, plant samples were collected three times in each of the four seasons over the 19-month study period: spring (March-May), summer (June-August), fall (SeptemberNovember), and winter (DecemberFebruary) (Table 2, Fig. 3). Phytophthora species were isolated most frequently in spring (seven isolates) and fall (eight isolates), and these two seasons accounted for $15(68 \%)$ of the 22 isolates recovered and, therefore, $68 \%$ of the infested plants. Phytophthora species were detected on only three plants during the summer months and on four plants during the winter months (Fig. 3). Different species of Phytophthora were detected on root samples at different times of the year with no obvious association between species and month of isolation. Only four species were isolated in multiple months: Phytophthora Clade 9 hybrids were isolated six times in five different months, $P$. drechsleri was isolated four times in three months, $P$. taxon personii was isolated three times in two months, and $P$. citrophthora was isolated twice: once in Mar. 2011 and once in Mar. 2012.

Association of Phrtophthora SPECIES WITH SPECIFIC SPECIES OF WETLAND PLANTS. In all, 14 plant species were sampled in the two wetland systems. Marsh dayflower and smooth beggartick had the highest incidence of infestation by species of Phytophthora at 33\% and 22\%, respectively (Table 1), even though only a few plants of these two species were sampled due to their limited distribution within both constructed wetland systems. Species more commonly used in the constructed wetland systems [e.g., California bulrush (Schoenoplectus californicus), broadleaf arrowhead, pickerelweed, and broadleaf cattail] all had lower incidences of infestation by Phytophthora species except for broadleaf arrowhead; 13\% of broadleaf arrowhead plants were infested. Phytophthora species were not isolated from these wetland species: duckweed, golden canna, lamp rush, and sedge (Table 1).

Seasonal patterns in species of Phytophthora associated with specific wetland plants were not observed (Table 2). Six isolates were recovered from roots of the two species of pennywort combined, two isolates of $P$. drechsleri and four isolates each of a different species. Three of six isolates were found during the month of March (spring), but the remaining 
Table 2. Species of Phytophthora were recovered from 10 wetland plant species growing in 9 of 16 collection sites at two constructed wetland systems located in a commercial plant nursery in Georgia in 2011 and $2012 .^{\mathrm{z}}$

\begin{tabular}{|c|c|c|c|c|}
\hline \multirow{2}{*}{$\underline{\text { Plant infested }}$} & \multirow[b]{2}{*}{ Phytophthora species } & \multirow[b]{2}{*}{ Collection site no. } & \multicolumn{2}{|c|}{ Date collected $^{\mathrm{z}}$} \\
\hline & & & Month & $\mathbf{Y r}$ \\
\hline \multirow[t]{3}{*}{ Alligatorweed } & Phytophthora Clade 9 hybrid & 1 & Sept. & 2012 \\
\hline & Phytophthora sp. ${ }^{\mathrm{x}}$ & 7 & May & 2012 \\
\hline & Phytophthora drechsleri ${ }^{\mathrm{w}}$ & 14 & Dec. & 2011 \\
\hline Broadleaf arrowhead & Phytophthora citrophthora ${ }^{\mathrm{v}}$ & 3 & Mar. & 2011 \\
\hline \multirow[t]{3}{*}{ Broadleaf cattail } & Phytophthora nicotianae ${ }^{t}$ & 2 & July & 2012 \\
\hline & Phytophthora taxon personii ${ }^{\mathrm{s}}$ & 7 & Mar. & 2012 \\
\hline & Phytophthora sp. ${ }^{\mathrm{x}}$ & 3 & Mar. & 2011 \\
\hline California bulrush & Phytophthora sp. ${ }^{\mathrm{x}}$ & 7 & Feb. & 2012 \\
\hline Maidencane & Phytophthora taxon personii ${ }^{\text {s }}$ & 10 & Nov & 2011 \\
\hline Marsh dayflower & Phytophthora Clade 9 hybrid & 2 & Sept. & 2012 \\
\hline Pickerelweed & $P$. taxon personii ${ }^{\mathrm{s}}$ & 12 & Nov. & 2011 \\
\hline \multirow[t]{2}{*}{ Smooth beggartick } & Phytophthora Clade 9 hybrid ${ }^{\mathrm{y}}$ & 3 & Nov. & 2011 \\
\hline & P. drechsleri & 3 & Dec. & 2011 \\
\hline \multirow[t]{3}{*}{ Water pennywort } & Phytophthora cryptogea ${ }^{\mathrm{q}}$ & 1 & Mar. & 2012 \\
\hline & Phytophthora Clade 9 hybridy & 2 & June & 2011 \\
\hline & P. drechsleri & 2 & Mar. & 2012 \\
\hline
\end{tabular}

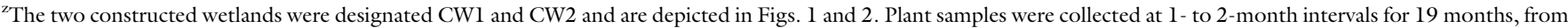
Mar. 2011 through Sept. 2012.

yutative Phytophthora hybrid in Clade 9: sequences of the nuclear ribosomal DNA internal transcribed spacer (ITS) locus had double peaks, and sequences from maternal mitochondrial genes $\operatorname{cox} 1$ and $\operatorname{cox} 2$ matched $100 \%$ the $\operatorname{cox} 1$ or $\operatorname{cox} 2$ sequences from National Center for Biotechnology Information (NCBI, Bethesda, MD) accession nos. MH477761-P. virginiana cox1, MF441670 - P. hydropathica coxl, JQ439448-P. hydropathica cox2, HQ261385-P. parsiana cox1, and GU222101-P. parsiana cox2. All $\operatorname{cox} 1$ and $\operatorname{cox} 2$ sequences from the six putative hybrids were identical, which suggested these isolates were clones.

${ }^{x}$ Phytophthora isolates not available for sequencing.

wITS sequence matched P. drechsleri: NCBI accession nos. AF266798, AY659464.

'ITS sequence matched $P$. citrophthora: NCBI accession nos. HQ643208, HQ643207.

uIT sequence matched $P$. inundata: NCBI accession no. AF541912.

${ }^{\mathrm{t}}$ ITS sequence matched $P$. nicotianae: NCBI accession no. AF266776.

sTS sequence matched $P$. taxon personii: NCBI accession no. EU301169.

${ }^{\mathrm{r}}$ ITS sequence matched P. virginiana: NCBI accession no. KC295542.

qITS sequence matched P. cryptogea: NCBI accession no. AY659450.

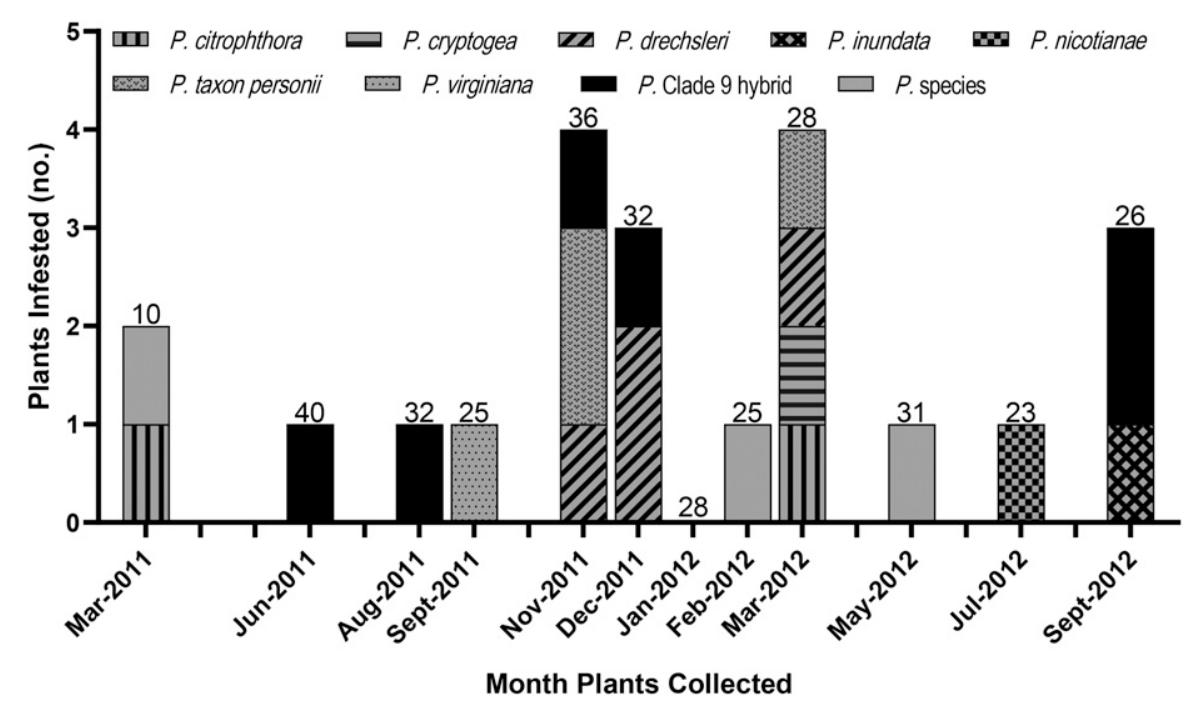

Fig. 3. Numbers of plants infested with species of Phytophthora at a commercial plant nursery in Georgia on 12 sampling dates (months) from Mar. 2011 through Sept. 2012. Plants were growing in runoff collection channels and constructed wetlands that received irrigation runoff water. Numbers above the bars are the total numbers of plants sampled on each sampling date. three isolates were found in two other seasons, summer (June) and fall (September and November) (Table 2). Four isolates were recovered from alligatorweed in at least two species, and each in a different season (Table 2).

Location of Phrtophthora SPECIES IN WETLAND SYSTEMS. LOCations of the sample sites (Figs. 1 and 2 ) were selected to represent various stages of water treatment by runoff collection channels and stages within the constructed wetland systems. In CWl (Fig. 1), 12 (16\%) of 73 sampled plants were found to be associated with species of Phytophthora in the runoff collection channel that received irrigation runoff coming from the nursery production area (sites $1-$ 3 ). Production runoff then flowed through the constructed wetland stages ( sites $4-8)$ where only $3(3 \%)$ of 93 sampled plants were infested. 
Runoff eventually flowed into the stilling ponds (site 9), where remaining sediment is removed from effluent before water is released off-site, and Phytophthora species were not associated with any of the 25 plants sampled at this site. In CW2 (Fig. 2), 4 (10\%) of 39 sampled plants were associated with Phytophthora species in the runoff collection channels (site 14 and 15) that received runoff coming from nursery production areas into the retention pond. In the three stages of the constructed wetlands (sites 10 12), 3 (5\%) of 63 sampled plants were associated with Phytophthora species; however, Phytophthora species again were not detected on 44 sampled plants in the two stilling ponds (sites 13 and 16), the site of water discharge from the wetlands.

A significant pattern existed between the presence of plants associated with Phytophthora species and location of these plants within the wetland system. Eighty percent (12 of 15 ) of plants in CWl and $57 \%$ (4 of 7) of plants in CW2 that were infested by species of Phytophthora were found in runoff collection channels receiving water from the plant production area. Fewer infested plants were found in the various stages of the two constructed wetlands systems. Phytophthora species were isolated from three plants collected from CWl site 7, which was located in the second stage of water treatment by the wetlands (Fig. 1). Each of these isolates was recovered from a different plant species (Table 2) on three separate sample dates. Species of Phytophthora were not detected at other sites in CW1. Within CW2, Phytophthora species were recovered from one plant collected from each of the three treatment stages (sites 10-12), but they were not detected on plants after the third wetland stage.

\section{Discussion}

Of the species of Phytophthora isolated in this study, only P. citrophthora, $P$. cryptogea, $P$. drechsleri, and P. nicotianae are well-known pathogens of woody ornamental plants (Erwin and Ribeiro, 1996), and these species accounted for only $8(36 \%)$ of the 22 isolates recovered. The other two species, P. inundata and $P$. virginiana, and $P$. taxon personii are relatively young species (i.e., identified for the first time in the past 25 years), typically are found in natural ecosystems or water habits, and are not known to be pathogenic to ornamental plants (Burgess et al., 2018; Yang and Hong, 2013). Likewise, Phytophthora Clade 9 hybrids appear to be related to species typically found in natural ecosystems and not to ones pathogenic to ornamental crops. Consequently, most of the isolates found associated with the roots of wetland plants were ones commonly found in waterways and natural settings.

Overall, a low percentage of the plants sampled throughout the runoff collection channels and stages of the constructed wetlands over the 19month study period were associated with species of Phytophthora; the roots of only $6.5 \%$ of 336 plants were infested. In addition, only $2.4 \%$ (8 of 336 plants) of the infested plants were associated with species of Phytophthora known to be pathogenic on woody ornamental plants. Of the wetland plants sampled, duckweed, golden canna, lamp rush, and sedge were never found to be associated with Phytophthora species. Samples from these four plant species accounted for $19 \%$ (64 of 336) of the samples processed.

Plants sampled in the spring and fall months, when air and water temperatures typically are moderate, were more likely to be infested ( 15 of 22 infested plants $=68 \%$ ) than plants sampled in the summer and winter months, when temperatures typically are more extreme. This seasonal pattern in plant root infestation was not unexpected, given that survival of some species of Phytophthora are negatively affected by temperatures below $13{ }^{\circ} \mathrm{C}$ and above $30^{\circ} \mathrm{C}$, and most species can actively grow and sporulate between 15 and $25^{\circ} \mathrm{C}$ (Erwin and Ribeiro, 1996; MacDonald and Duniway, 1978). However, no obvious seasonal patterns of infestation of individual plant species were observed, with infested plants of each wetland species found in different months in several seasons. Consequently, seasonal management of the wetland system to limit infestation of plants that harbor potential plant pathogens may not be necessary, because season did not appear to influence frequency of infestation of wetland plants established in the constructed wetlands at this nursery.
Phytophthora species were less likely to be associated with plants growing in the later stages of the constructed wetlands. The authors are aware of only one other study that has investigated the distribution of Phytophthora species within a constructed wetland system (Headley et al., 2005); in this study, researchers found that Phytophthora cinnamomi was not detectable in water leaving a constructed wetland system containing common reed (Phragmites australis) after a high concentration of inoculum was introduced into water entering the constructed wetland system. These findings show promise for the use of constructed wetlands to reduce inoculum densities of Phytophthora species in runoff and prevent inoculum escaping into the environment or returning to the production area if water is captured and reused. This suggests that viable propagules, presumably zoospores, were trapped or eliminated by biological filtration as infested water passed through the wetland system. Some mechanisms innate to biological filtration include predation by competing microorganisms, attack by lytic bacteria, attachment to biofilms, inactivation by bacteriophages or toxins, and natural die-off (Vymazal, 2008; Weber-Shirk and Dick, 1997); therefore, it is possible that one or more of these processes could limit zoospore activity and survival in constructed wetland systems. Most of the mechanisms that involve removal or transformation of organic substances are accomplished through microbial processing (Hammer, 1992). The results from our study concur with other studies on removal of human pathogens by constructed wetlands. Kamizoulis (2005) and Garcia et al. (2003) reported that tertiary-treatment constructed wetlands associated with wastewater treatment facilities effectively decreased numbers of bacteria, protozoa, and viruses.

Species of Phytophthora were isolated from $15.4 \%$ of the roots from alligatorweed plants and $6.7 \%$ of the roots from California bulrush plants. Plants of both of these species that were growing in the late stages of CWl (site 7) were found to be associated with species of Phytophthora. Broadleaf arrowhead was used to establish both CW1 and CW2 and had a $12.5 \%$ incidence of root infestation. 
Further research should be conducted to investigate the susceptibility of these three wetland species to multiple species of Phytophthora and the potential for these plants to serve as sources of inoculum and, therefore, to release zoospores of Phytophthora species into constructed wetland systems. Phytophthora species were not found on roots of golden canna, lamp rush, duckweed, and sedge, but these species currently are not commonly used in constructed wetlands. The use of these wetland plants in constructed wetlands should be reevaluated.

The plant species with the highest incidences of infestation by Phytophthora species consisted of one native and two exotic invasive species. Smooth beggartick, a native plant species, was collected nine times with two plants having infested roots. This is a relatively small sampling number, so these results need to be verified using a greater number of plants. More important, the incidence of infestation by Phytophthora species on the exotic invasive species marsh dayflower and alligatorweed was $33.3 \%$ and $15.4 \%$, respectively. Marsh dayflower is a moderately invasive [Category 2 (White et al., 2012)] herbaceous perennial species that spreads vegetatively by fragmentation, and alligatorweed is considered a seriously invasive herbaceous perennial species that is known to spread by producing vegetative propagules (White et al., 2012). Thus, management and eradication of these two herbaceous perennial species in nursery settings may be necessary, as our research shows they have the potential to become associated with at least one species of Phytophthora (i.e., P. drechsleri) known to be pathogenic to ornamental plants. This may serve as another reason to eliminate invasive plants from runoff channels and constructed wetland systems.

These findings provide an important first look at the associations between wetland plants and species of Phytophthora in constructed wetland systems used to treat irrigation runoff from commercial plant nurseries and will serve to further optimize constructed wetlands for the removal of chemical contaminants and propagules of plant pathogens. Plant species that are commonly used in constructed wetlands and show the most promise as biological filters include golden canna, marsh pennywort, pickerelweed, and broadleaf cattail. Although most of these plant species were found to be infested during this study, the highest incidence of infestation was only $5.5 \%$ of the total number of plants sampled for a particular species. Further studies on root infection rather than surface infestation of these plant species are needed to produce a better understanding of the susceptibility of wetland plant species to species of Phytophthora.

\section{Literature cited}

Agency for Toxic Substances and Disease Registry. 2010. Toxicological profile for chlorine. 21 Mar. 2019. <http://www. atsdr.cdc.gov/ToxProfiles/tp172.pdf>

Burgess, T.I. 2015. Molecular characterization of natural hybrids formed between five related indigenous clade 6 Phytophthora species. PLoS One 10:e134225.

Burgess, T.I., A.V. Simamora, D. White, B. Williams, M. Schwager, M.J.C. Stukely, and G.E.St.J. Hardy. 2018. New species from Phytophthora Clade 6a: Evidence for recent radiation. Persoonia 4l:117.

Choi, Y.-J., G. Beakes, S. Glockling, J. Kruse, B. Nam, L. Nigrelli, S. Ploch, H. Shin, R.G. Shivas, S. Telle, H. Voglmayr, and $M$. Thines. 2015. Towards a universal barcode of oomycetes-A comparison of the cox 1 and cox 2 loci. Mol. Ecol. Resour. 15:1275-1288.

Cooke, D.E.L., A. Drenth, J.M. Duncan, G. Wagels, and C.M. Brasier. 2000. A molecular phylogeny of Phytophthora and related oomycetes. Fungal Genet. Biol. 30:17-32.

Erwin, D.C. and O.K. Ribeiro. 1996. Phytophthora diseases worldwide. Amer. Phytopathol. Soc., St. Paul, MN.

Ferguson, A.J. and S.N. Jeffers. 1999. Detecting multiple species of Phytophthora in container mixes from ornamental crop nurseries. Plant Dis. 83:1129-1136.

Garcia, J., J. Vivar, M. Aromir, and R. Mujeriego. 2003. Role of hydraulic retention time and granular medium in microbial removal in tertiary treatment reed beds. Water Res. 37:2645-2653.

Grünwald, N.J., F.N. Martin, M.M. Larsen, C.M. Sullivan, C.M. Press, M.D. Coffey, E.M. Hansen, and J.L. Parke. 2011. Phytophthora-ID.org: A sequencebased Phytophthora identification tool. Plant Dis. 95:337-342.

Hammer, D.A. 1992. Designing constructed wetlands systems to treat agri- cultural nonpoint source pollution. Ecol. Eng. 1:49-82.

Headley, T., J. Dirou, D. Huett, G. Stovold, and L. Davison. 2005. Reed beds for the remediation and recycling of nursery runoff water. Australas. J. Environ. Mgt. 12:27-36.

Hong, C.X. and G.W. Moorman. 2005. Plant pathogens in irrigation water: Challenges and opportunities. CRC Crit. Rev. Plant Sci. 24:189-208.

Hong, C., G.W. Moorman, W. Wohanka, and C. Büttner (eds.). 2014. Biology, detection, and management of plant pathogens in irrigation water. Amer. Phytopathol. Soc., St. Paul, MN.

Jeffers, S.N. 2015a. Protocol 07-11.1: V8 agar (V8A) or broth. In: K. Ivors (ed.). Laboratory protocols for Phytophthora species. Amer. Phytopathol. Soc., St. Paul, MN. <http://dx.doi.org/10.1094/ 9780890544969.07.11.1>.

Jeffers, S.N. 2015b. Protocol 0704.1: PARP(H)-V8A. In: K. Ivors (ed.). Laboratory protocols for Phytophthora species. Amer. Phytopathol. Soc., St. Paul, MN. <http://dx.doi.org/10.1094/ 9780890544969.07.04.1>.

Jeffers, S.N. 2015c. Protocol 07-12.1: Super V8 agar (sV8) In: K. Ivors (ed.). Laboratory protocols for Phytophthora species. Amer. Phytopathol. Soc., St. Paul, MN. <https://doi.org/10.1094/ 9780890544969.07.12.1>.

Jeffers, S.N. and H.S. Aldwinckle. 1987. Enhancing detection of Phytophthora cactorum in naturally infested soil. Phytopathology 77:1475-1482.

Jeffers, S.N. and H.S. Aldwinckle. 1988. Phytophthora crown rot of apple trees: Sources of Phytophthora cactorum and $P$. cambivora as primary inoculum. Phytopathology 78:328-335.

Kamizoulis, G. 2005. The new draft WHO guidelines for water reuse in agriculture, p. 209-220. Proc. Tech. Wkshp. Integration of Reclaimed Water in Water Resource Management, Lloret de Mar, Spain.

Klotz, L.J., P.P. Wong, and T.A. DeWolfe. 1959. Survey of irrigation water for the presence of Phytophthora species pathogenic to citrus. Plant Dis. Rptr. 43:830-832.

MacDonald, J.D., A. Abeliovich, D. Faiman, J. Kabashima, and M. LagunasSolar. 1997. Treatment of irrigation effluent water to reduce nitrogenous contaminants and plant pathogens. BARD Sci. Rpt., Bet Dagan, Israel.

MacDonald, J.D. and J.M. Duniway. 1978. Temperature and water stress 
effects on sporangium viability and zoospore discharge in Phytophthora cryptogea and $P$. megasperma. Phytopathology 68:1449-1455.

Majsztrik, J.C., R.T. Fernandez, P.R. Fisher, D.R. Hitchcock, J. Lea-Cox, J.S. Owen, Jr., L.R. Oki, and S.A. White. 2017. Water use and treatment in container-grown specialty crop production: A review. Water Air Soil Pollut. 228:151.

Martin, F.N., J.E. Blair, and M.D. Coffey. 2014. A combined mitochondrial and nuclear multilocus phylogeny of the genus Phytophthora. Fungal Genet. Biol. 66:19-32.

McIntosh, D.L. 1966. The occurrence of Phytophthora species in irrigation systems in British Columbia. Can. J. Bot. 44:1591-1596.

Pettitt, T.R., A.R. Finlay, M.A. Scott, and E.M. Davies. 1998. Development of a system simulating commercial production conditions for assessing the potential spread of Phytophthora cryptogea root rot of hardy nursery stock in recirculating irrigation water. Ann. Appl. Biol. 132:61-75.

Shokes, F.M. and S.M. McCarter. 1979. Occurrence, dissemination and survival of plant pathogens in surface irrigation ponds in south Georgia. Phytopathology 69:510-516.

Stewart-Wade, S.M. 2011. Plant pathogens in recycled irrigation water in commercial plant nurseries and greenhouses: Their detection and management. Irr. Sci. 29:267-297.

Taylor, M.D., S.A. White, S.L. Chandler, S.J. Klaine, and T. Whitwell. 2006. Nu- trient management of nursery runoff water using constructed wetland systems. HortTechnology 16:610-614.

Vymazal, J., M. Greenway, K. Tonderski, H. Brix, and U. Mander. 2006. Constructed wetlands for wastewater treatment, p. 69-96. In: J.T.A. Verhoeven, B Beltman, R. Bobbink, and D.F. Whigham (eds.). Wetlands and natural resources management. Springer Verlag, BerlinHeidelberg, Germany.

Vymazal, J. 2008. Constructed wetlands for wastewater treatment: A review, p. 965-980. In: M. Sengupta and R Dalwani (eds.). Proc. Taal 2007: The 12th World Lake Conf. 28 Oct.-2 Nov. 2007. Jaipur, India.

Vymazal, J. 2011. Constructed wetlands for wastewater treatment: Five decades of experience. Environ. Sci. Technol. 45:6169.

Weber-Shirk, M.L. and R.I. Dick. 1997. Biological mechanisms in slow sand filters. J. Amer. Water Works Assn. 89:72-83.

White, S.A. 2018. Design and season influence nitrogen dynamics in two surface flow constructed wetlands treating nursery irrigation runoff. Water $10(1): 8$. DOI:10.3390/w10010008.

White, T.J., T. Bruns, S. Lee, and J. Taylor. 1990. Amplification and direct sequencing of fungal ribosomal RNA genes for phylogenetics, p. 315-322. In: M.A. Innis., D.H. Gelfand, J.J. Sninsky, and T.J. White (eds.). PCR protocols: A guide to methods and applications. Academic Press, New York, NY.
White, S.A., J.S. Owen, J.C. Majsztrik, R.T. Fernandez, P. Fisher, C.R. Hall, T. Irani, J.D. Lea-Cox, J.P. Newman, and L.R. Oki. 2013. Grower identified priorities for water research in ornamental crops. Southern Nursery Assn. Res. Conf. Proc 58:299-301.

White, S.A., M.D. Taylor, S.L. Chandler, T. Whitwell, and S.J. Klaine. 2010. Remediation of nitrogen and phosphorus from nursery runoff during the spring via free water surface constructed wetlands. J. Environ. Hort. 28:209-217.

White, S.A., M.D. Taylor, and D.Z. Damrel. 2012. Floral colonization of a free water surface constructed wetland system in Grady County, Georgia. Castanea 77:13-16.

Whiteside, J.O. and T.W. Oswalt. 1973. An unusual brown rot outbreak in a Florida citrus grove following sprinkler irrigation with Phytophthora-infested water. Plant Dis. Rptr. 57:391-393.

Yamak, F., T.L. Peever, G.G. Grove, and R.J. Boal. 2002. Occurrence and identification of Phytophthora species pathogenic to pear fruit in irrigation water in the Wenatchee river of Washington state. Phytopathology 92:1210-1217.

Yang, X. and C. Hong. 2013. Phytophthora virginiana sp. nov., a high-temperature tolerant species from irrigation water in Virginia. Mycotaxon 126:167176.

Yang, X., B.M. Tyler, and C. Hong. 2017. An expanded phylogeny for the genus Phytophthora. IMA Fungus 8:355-384. 